\title{
Analysis of Status of Oral Stunting in Toddlers and Its Relationship with Mother's Parenting
}

\author{
Munifah Abdat ${ }^{1, *}$ Chairunas Chairunas ${ }^{2}$ \\ ${ }^{1}$ Faculty of Dentistry, Universitas Syiah Kuala, Aceh, Indonesia \\ ${ }^{2}$ Faculty of Dentistry, Universitas Syiah Kuala, Aceh, Indonesia \\ *Corresponding author.Email: munifahabdatdr@unsyiah.ac.id
}

\begin{abstract}
Decreased physical growth and low cognitive development optimally experienced by stunting toddlers, due to nutritional deficiencies in the long term. Stunting in toddlers does not only affect the eruption of the primary teeth, it is also at risk for the occurrence of dental caries. The condition of children who experience malnutrition affects the health of the oral cavity and vice versa the health of the oral cavity can have an impact on poor nutrition. Mother's parenting pattern also determines the nutritional status of toddlers, especially in the selection of food consumed by toddlers. The aim of the study was to analysis the dental-mouth status in stunting (short) toddlers and their relationship to maternal parenting. This research method was carried out by purposive sampling in eight villages in Banda Aceh, the subjects obtained were 38 stunting toddlers. Data were obtained through interviews using a questionnaire and dental and oral examination using the deft index and OHIS. The results showed that the dental caries status was high in stunting toddlers (deft=5.71). On average, each toddler has 6 carious baby teeth and poor parenting patterns. It was found that a significant relationship between stunting and oral hygiene where the lower the nutritional status (stunting), the lower the oral hygiene of toddlers. It was concluded that toddlers with stunting had high dental caries status and poor maternal parenting.
\end{abstract}

Keywords: Stunting, dental caries, parenting, OHIS.

\section{INTRODUCTION}

According to global data, it is estimated that $26 \%$ of children under five worldwide experience stunting.[1] Stunting or shortness is the condition of a child with a shorter height than children his age due to chronic malnutrition from in the womb until the child is born (the first 1000 days of life) and only appears after the child is 2 years old.[2] Based on the WHO report, Indonesia is the country with the fourth highest prevalence of stunting in the world, with a prevalence rate of 36\%.[3] The 2018 Riskesdas results report that the prevalence of stunting in Aceh is in the third highest position after the provinces of NTB and Sulawesi. West for groups of children under five in Indonesia.[4] The city of Banda Aceh according to the results of a survey on monitoring the nutritional status of Aceh in 2017 showed a stunting rate of $17.7 \%$.[5]

The causes of stunting are multifactorial and complex, one of the underlying causes is socioeconomic status, while the direct causes are inappropriate food intake and imbalance in nutritional content in food, history of low birth weight (LBW) and disease history.[1] Maternal parenting, especially food intake for toddlers, has an effect on growth and development, furthermore it is said that malnutrition in toddlers can be irreversible.[6] Research by Nabuasa et al. states that mother's parenting pattern on her child's food intake determines the nutritional status of toddlers, the better the food intake, the better the nutritional status. [7] Good food intake is described thought the diversity of food consumption and a reflection of the nutritional adequacy of a toddler.[8], [9]

The impact of children who experience chronic malnutrition (stunting) is that their salivary secretion will be inhibited due to atrophy of the salivary glands so that the salivary flow rate is reduced.[10] The salivary flow rate affects the occurrence of dental caries.[11] When the salivary flow rate decreases, the active content in the saliva is serves to protect teeth from caries will be inhibited and vice versa.[11] The results of the study by Jones PC at al found that primary dental caries was more prevalent in malnourished children.[12] Deciduous teeth that fall out late will be exposed to food for longer and are at risk of increasing primary dental caries, not only In addition, it was found that the delay in the eruption of permanent replacement teeth was also associated with malnutrition.[12]

Caries status for primary teeth was calculated by index def-t, $d$ (decay) for carious teeth, e (extracted) for teeth that were extracted due to caries and about to grow permanent teeth, and f (filling) for teeth that have been restored.[13] Oral hygiene is important to note because it describes general health conditions.[14] Examination of 
oral hygiene status is carried out by measuring the Oral Hygiene Index Simplified (OHI-S) by assessing debris and calculus scores from 6 teeth.[13] The occurrence of fermentation of food debris in the mouth by microorganisms such as S. mutans, S. sanguis, Lactobacillus acidophilus, Actinomyces viscosus in plaque and saliva, can progress to dental caries.[15]

Epidemiological studies have shown that there is a causal link between malnutrition and dental caries.[16],[17] Stunting can lead to impaired maturation of the teeth, impaired development of tooth enamel and delayed eruption of primary teeth.[16] Preventing and treatment the caries in early childhood will improve oral health, nutrition and health. and health in general.[16] This study aimed to analyze the dental-mouth status in stunted toddlers and their relationship to maternal parenting.

\section{RESEARCH METHODOLOGY}

A cross-sectional study was conducted in November-December 2019. The research locations were in six villages in the Baiturrahman sub-district, Banda Aceh city, Aceh, Indonesia. Initial data is based on secondary data obtained from e-PPGBM data from the nutrition section of Baiturrahman sub-district, Banda Aceh city. The subjects of this study were selected through purposive sampling technique. The subjects of this study were 38 stunted toddlers and their mothers based on inclusion criteria, namely toddlers aged 2-5 years with stunting and their parents were willing to be research subjects, had erupted the toddler's primary teeth and no history of systemic disease.

The flow of this research begins with obtaining a research permit from the Baiturrahman sub-district, Banda Aceh, and an application for permission from the village midwife in the Baiturrahman area of Banda Aceh. The research subjects were visited door to door based on the address obtained previously, then the researcher provided concern information and questionnaires as research instruments for each mother of stunting toddlers. After that, the researchers screened the toddler's teeth using the DMFT index and OHI-S examination. Parenting patterns were obtained from the results of the questionnaire data that had been filled out by the mothers.

The data from the examination are recorded in the DMF-T and OHI-S forms which are provided in tabular form. Data that has been collected was analysis by frequency distribution using microsoft excel 2016. Followed by processing data analysis using SPSS 24.0 with Chi square test and Kendall Tau test, also significant value $\mathrm{p}<0.05$.

\section{RESULT AND REVIEW}

\subsection{Basic Characteristics of Research Subject}

The general characteristics of the subject in this study were grouped by gender and age. Shown in the table 1 , the number of subjects was 19 people $(50 \%)$ the same for male and female subjects with a total of 38 people. Different from the traditional research where there are more female stunting children than male stunting children.[18]

Table 1. Frequency Distribution by Gender and Age

\begin{tabular}{|c|c|c||}
\hline $\begin{array}{c}\text { Characteristics of } \\
\text { Respondent }\end{array}$ & Frequency & $\%$ \\
\hline Gender & 19 & 50 \\
\hline Male & 19 & 50 \\
\hline Female & 12 & \\
\hline Age & 8 & 31.57 \\
\hline 2 years & 13 & 21.05 \\
\hline 3 years & 5 & 34.21 \\
\hline 4 years & & 13.15 \\
\hline 5 years & \\
\hline
\end{tabular}

Figure 1. Categories of parenting styles for mothers with stunting toddlers

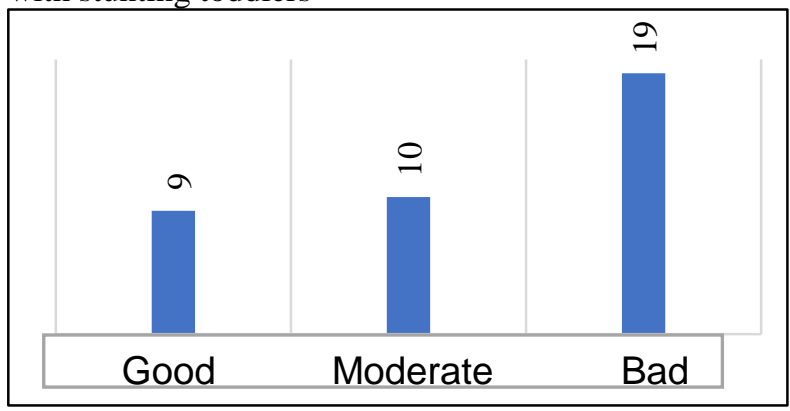

Figure 1. The results showed that the parenting pattern with the bad category was 19 mothers, followed by 10 in the moderate category and 9 in the good category. From the diagram, we can see that poor parenting is still dominated by stunting toddlers in Baiturrahman sub-district.

Parenting related to food intake will affect the growth and development of toddlers, therefore quality food intake is needed.[19] In line with the results of Nabuasa's research, Juffrie et al who stated that maternal parenting related to food intake determines the nutritional status of toddlers, if the food is good, the nutritional status is better.[7] Food intake in toddlers should meet the diversity of food consumption and reflect the level of nutritional adequacy of toddlers.[8], [20] 
The results of Nasrul et al's research found that the determinants of stunting were hygiene factors, due to the behavior of mothers or caregivers who did not wash their hands with soap before feeding their children $(\mathrm{OR}=1.765$ (1.091-2.854).[21] We found a lower proportion of stunting in mothers who washed their hands compared with mothers who do not wash their hands regularly.[21] This is reinforced by research by Rah et al. which states that the habit of mothers or caregivers washing their hands with soap before feeding their children or after defecating can reduce the risk of stunting by up to $15 \%$.[22]

Several studies have reported that a low diversity of foods such as animal protein, vegetables and fruits is associated with an increased risk of stunting.[23] Research conducted by Dewi and Nindya in Gresik in 2017 stated the importance of intake of green vegetables such as spinach because of the iron content in green vegetables, iron is then stored in the spine and used to produce hemoglobin, thereby reducing the risk of stunting.[24 ] On the other hand, if the amount of iron in the body is not sufficient and lasts for a certain time, it can result in anemia and lower immunity, susceptible to disease and affect the linear growth of toddlers.[25]

The results of this study showed that more than $68.4 \%$ of mothers gave breast milk to their toddlers until the age of 2 years. In line with Yogi's research, Yenni et al. conducted in Jatinangor District in 2017 on stunting toddlers, the results obtained from 65 mothers of stunted toddlers were $49.2 \%$ breastfed until the age of 2 years.[25] Another study conducted by Pengan J, Kawengian S et al in 2015 showed the same thing, as more than $50 \%$ of mothers gave breast milk until the age of 2 years for stunted toddlers in the Banggai Regency, Central Sulawesi.[26] Growth and development in infants requires balanced nutrition. The only intake that is in accordance with the condition of the baby's digestive organs and fulfills their needs from birth is Mother's Milk (ASI).[27] Infants who are not exclusively breastfed are at a higher risk of malnutrition and stunting in children.[27], [28]

The results showed that $44.7 \%$ of mothers admitted to giving formula milk from under 1 year of age and more than $57.9 \%$ gave packaged milk. Consumption of too much packaged milk will cause children to become full and actually cause nutritional deficiencies.[29] Provision of standard formula milk as a complementary food is considered in order to fulfill nutrition so as not to experience micronutrient deficiencies.[28] Micronutrients such as Zinc, Fe, Vit.A, and Vit.D are nutrients contained in standard formula milk.[30], [31] The highest caries rate in Baiturrahman sub-district was in Ateuk Deah Tanoh village with 9 children, while the village with the lowest caries rate was in Peuniti village with 8 children. On average, each stunting toddler has 6 teeth with caries. The def-t index in the Baiturrahman area is included in the high category (def-t=5.71). In line with Rahman, Andani et al's research conducted in Kertak Hanyar District, Banjar Regency, the result of stunting children's def-t was 8.23 and categorized as very high.[32] This shows that stunted children have a high caries rate. It was found that stunting in toddlers affects the eruption time of primary teeth and increases the risk of dental caries.[32]

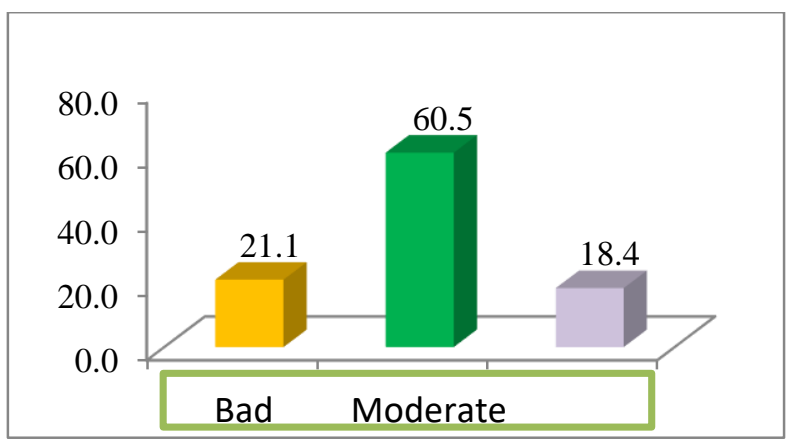

Figure 2 Oral hygiene category based on the OHIS index in stunting toddlers

Figure 2 shows that the highest level of dental hygiene for stunting toddlers is in the moderate category at $60.5 \%$, followed by the bad category at $21.1 \%$ and the good category at $18.4 \%$. Good dental hygiene can affect a person's quality of life, such as: chewing, eating, swallowing and speaking. Poor oral hygiene in the presence of calculus and stains, the number of dental caries, and the absence of teeth can cause health problems.[15]

\subsection{Relationship Oral Health Status to Maternal Parenting}

Table 2. Test of Variance on Caries, Oral Hygiene and Parenting

\begin{tabular}{|l|r|r|r|}
\hline & \multicolumn{1}{|c|}{ Caries } & \multicolumn{1}{c|}{$\begin{array}{c}\text { Oral } \\
\text { Hygiene }\end{array}$} & \multicolumn{1}{|c|}{ Parenting } \\
\hline Chi-Square & $27.684^{c}$ & $12.684^{\mathrm{d}}$ & $34.000^{\mathrm{a}}$ \\
\hline Df & 12 & 2 & 7 \\
\hline Asymp. Sig. & .006 & .002 & .000 \\
\hline
\end{tabular}

Chi Square test. Sig. $p<0.05$

Table 3. Correlation of parenting, caries dental and oral hygiene in stunting toddlers

\begin{tabular}{llllc}
\hline \multirow{2}{*}{$\begin{array}{l}\text { Kendal } \\
\text { 's }\end{array}$} & \multicolumn{2}{c}{$\begin{array}{c}\text { Paren } \\
\text { ting }\end{array}$} & Caries & $\begin{array}{c}\text { Oral } \\
\text { Hygiene }\end{array}$ \\
\multirow{2}{*}{ tau b Stunting } & $\begin{array}{l}\text { Correlation } \\
\text { Coefficient }\end{array}$ & .011 & -.052 & .082 \\
\cline { 2 - 5 } & $\begin{array}{l}\text { Sig. (2- } \\
\text { tailed) }\end{array}$ & .927 & .665 & .534 \\
\cline { 2 - 5 } & $\mathrm{N}$ & 38 & 38 & 38
\end{tabular}

Kendall tau test. Sig. $\mathrm{p}<0.05$ 
Table 2 shows the caries sig value of 0.006 $(<0.05)$, which means that there is a variation in the number of dental caries in stunting toddlers. The results of the study showed that the highest caries score was 14 and the lowest caries score was 0 . On average, each stunted toddler was found to have 6 teeth with caries. It was found that the OHI-S sig value was $0.002(<0.05)$, which means that there was a variation in the results of oral hygiene examination for stunting toddlers. Parenting patterns show a sig value of $0.00(<0.05)$, meaning that there are variations in parenting given by mothers to stunting toddlers, most toddlers still get bad parenting from their mothers.

The results of the Kendall tau correlation test, between nutritional status and parenting, caries and OHI$\mathrm{S}$. The score of the relationship between stunting and parenting is 0.011, indicating that the higher the parenting pattern, the better the nutritional status of the stunting toddler. The incidence of stunting in toddlers is influenced by parenting related to food intake. Research by Widyaningsih, Kusnandar et al33 showed that $51.2 \%$ of stunting toddlers had a poor dietary intake pattern, that there was a significant relationship between dietary intake patterns and stunting incidence $(\mathrm{p} \leq 0.05)$.

The stunting nutrition score with caries of 0.052 states that the lower the nutritional status of children under five (stunting), the higher the caries. In accordance with Rahman's research, Andani et al stated that there was a relationship between stunting nutritional status and caries levels in children.[32]

Stunting with Oral Hygiene has a value of 0.082 stating that the better the oral hygiene, the higher the nutritional status of stunting toddlers. In line with the research by Sheetal, Hiremath, Kumar et al, who said that poor nutrition affects oral health and oral health can also lead to poor nutrition.[34]

In addition, the results of Nabuab et al's study also stated that there was a positive correlation between poor nutritional status and the severity of dental caries, where caries in deciduous and permanent teeth was higher in children with poor nutritional status than children with good nutritional status.[17]

\section{CONCLUSION}

Based on the research, it can be concluded that there is a relationship between stunting and caries where the lower the nutritional status of toddlers (stunting), the higher the caries frequency. The high frequency of caries has something to do with maternal parenting. Based on the results, it was found that there was a relationship between stunting and Oral Hygiene where the higher the nutritional status, the better the Oral Hygiene of toddlers.

\section{ACKNOWLEDGMENTS}

The author would like to thank the Health Community Centre of Baiturrahman sub-district Banda Aceh City for permission and facilitating this research process.

\section{REFERENCES}

[1] Black RE, Allen LH, Bhutta ZA, Caulfield LE, de Onis M, 1. Rivera J, et al. Maternal and child undernutrition: global and regional exposures and health consequences. Lancet 2008;371(9608):243-60.

[2] Ministry of Villages, Development of Disadvantaged Regions, and Transmigration of the Republic of Indonesia 2017. Pocket Book on Villages in Handling Stunting. Jakarta: Ministry of Villages, Development of Disadvantaged Regions, and Transmigration of the Republic of Indonesia; 2017

[3] WHO. The Double Burden of Malnutrition. Policy brief. Geneva. 2017

[4] Report on the Nutrition Status Monitoring Survey of Aceh Province 2017. Monitoring and Evaluation Study of the Nutrition Program of PSG and PKG Aceh. Banda Aceh, the Aceh Health Service in collaboration with the Health Poltekkes of the Aceh Ministry of Health; 2018.

[5] Health Research and Development Agency of the Indonesian Ministry of Health. Basic Health Research. Jakarta; 2018. P 557

[6] Martianto D, Riyadi H, Ariefiani R. Dietary Parenting in Food Resistant and Insecure Households and Its Relation to the Nutritional Status of Toddlers in Banjarnegara Regency. J Nutrition and Food. 2011;6(1):51-58.

[7] Nabuasa, C.D, Juffrie, M, and Huriyati E. History of parenting, diet, nutrient intake related to stunting in children 24-59 months of age in North Biboki, North Central Timor, East Nusa Tenggara. J Nutrition and Diet Indonesia. 2013;1(3):31-43.

[8] Baliwati Y farida, Briawan D, Melani V. Development of an Instrument for Quality Assessment of Food Consumption in Poor Households in Indonesia. Indonesian nutrition. 2015;38(1):63-71.

[9] Kennedy G, Ballard T, Dop M. Guidelines for Measuring Household and Individual Dietary Diversity. Roma (IT): FAO;2011. 
[10] Mahadevan K, Velavan S. Analysis of Salivary Proteins As The Biochemical Indicators of Nutritional Status and Salivary Gland Function. International Journal Pharmacy Biology Science. 2013; 4(2): p.689-694

[11] Yas B, Jafer N, Radhi. Salivary Viscosity in Relation to Oral Health Status among a Group of 20-22 Years Old Dental Students. Iraqi Journal Community Medical. 2013;3(23):219-24.

[12] Jones PC, Richardson BD, Granath L, Fatti LP, Sinwell R, Walker AR, et al. Nutritional Status and Dental Caries in a Large sample of 4 and 5 year old South African Children. S A J Clin. 2000; 90(6): p.631-635

[13] Blue Christine M.Darby's Comperhensive Review of Dental Hygiene 8th edition. 2017. Riverport Lane:Elsevier. p.5-638

[14] Abdat. M. Mother's Knowledge and Attitude Regarding Her Child's Primary Teeth and Willingness to Take Care. Cakradonya Dental Journal; 2018; 10(1): 18-26

[15] Satria B, Sutadi $H$ dan Mangundjaja S. The differences level of CFU of mutans streptococci in saliva of schoolchildren during fasting and non-fasting. Jakarta: Department of Pediatric Dentistry and Department of Oral Biology Faculty of Dentistry Universitas Indonesia. 2009; p.2-3

[16] Marvin So, Yianni A. Ellenikiotis, Hannah MH, Cecilia LP, Brittany S, et al. Early Childhood Dental Caries, Mouth Pain, and Malnutrition in the Ecuadorian Amazon Region. International Journal of Environ. Research Public HealthI. $2017 ; 14: 1-9$

[17] Nabuab JD, Duijster D, Benzian H, Wetzien RH, Homsavath A, Monse B, at al. Nutritional Status, Dental Caries and Tooth Eruption in Children: A longitudinal Study in Camboja, Indonesia and Lao PDR. BMC Pediatrics. 2018; 18 (300): p.111

[18] Abdat M, Usman S, Chairunas, Suhaila H. Relationship Between Stunting With Dental and Oral Status in Toddlers. J Dentomaxillofac Sci. 2020;5(2):114-19

[19] Martianto D, Riyadi H, Ariefiani R. Dietary Parenting in Food Resistant and Insecure Households and Its Relation to the Nutritional Status of Toddlers in Banjarnegara Regency. J Nutrition and Food. 2011;6(1):51-58.
[20] Kennedy G, Ballard T, Dop M. Guidelines for Measuring Household and Indivi dual Dietary Diversity. Roma (IT): FAO; 2011.

[21] Nasrul, Hafid F, Thaha AR, Syria. Risk Factors for Stunting Age 6-23 Months in Bontoramba District, Jeneponto Regency. MKMI Journal; 2015:139-146.

[22] Rah JH, Cronin AA, Badgaiyan B. Household Sanitation and Personal Hygiene Practices are Associated with Child Stunting in Rural India: a Cross-Sectional Analysis of Surveys. BMJ Open.2015;5(1):155. doi:10.1136/bmjopen2014-005180

[23] Ochola S, Masibo PK. Dietary Intake of Schoolchildren and Adolescents in Developing Countries. Ann NutrMetab. 2014;64(2):24-40.

[24] Dewi E, Nindya T. The Relationship between Iron and Zinc Adequacy Levels with Stunting Incidence in Toddlers 6-23 Months. Amerta Nutr. 2017;1(4):361.

[25] Dwitama YS, Zuhairini Y, Djais J. The relationship between exclusive breastfeeding and complementary foods for short toddlers aged 2 to 5 years in Jatinangor District. JKS.2018;3(3):145.

[26] Pengan J, Kawengian S, Rombot DV. The Relationship Between Exclusive Breastfeeding History and Stunting Incidence in Children 12-36 Months Old in the Work Area of the Luwuk Health Center, South Luwuk District, Banggai Regency, Central Sulawesi. Sam Ratulangi Faculty of Public Health, Manado. JOM. 2015; $5(2): 3-5$.

[27] Anshori, H. Risk Factors for Stunting in Children aged 12-24 Months (study in East Semarang District). Semarang: Universitas Diponegoro; 2013.

[28] Mediana S, Pratiwi R. The Relationship between the Amount of Standard Formula Milk Consumption on the Incidence of Stunting in Children aged 2-5 Years. JKD. 2016;5(4):1744.

[29] Zulkarnain MR. For Toddlers Better Sufor or UHT Yes. Food for Kids Indonesia.2016; 4(9): $14-15$

[30] Pereira PC. Milk nutritional composition and its role in human health. Science Direct. 2014;30(6):619-627. 
[31] WHO. Global Nutrition Targets 2025: Stunting Policy Brief. Geneva: World Health Organization. 2014

[32] Rahman T, Adhani R, Triawanti. The Relationship Between Short Nutritional Status (Stunting) With Dental Caries Level. Dentino jurnal kedokteran gigi. 2016; 1(1):88-93.

[33] Widyaningsih NN, Kusnandar, nantanyu S. Keragaman Pangan, Pola Asuh Makan dan Kejadian Stunting pada Balita Usia 24-59 Bulan. The Indonesian Journal of Nutrition.2018;7(1):27.

[34] Sheetal A, Hiremath VK, Patil AG, Sajjansetty S, Kumar SR. Malnutrition and Its Oral Outcome-A Review. Jurnal of clinical and diagnostic research. 2013; 7(1): 178-180. 